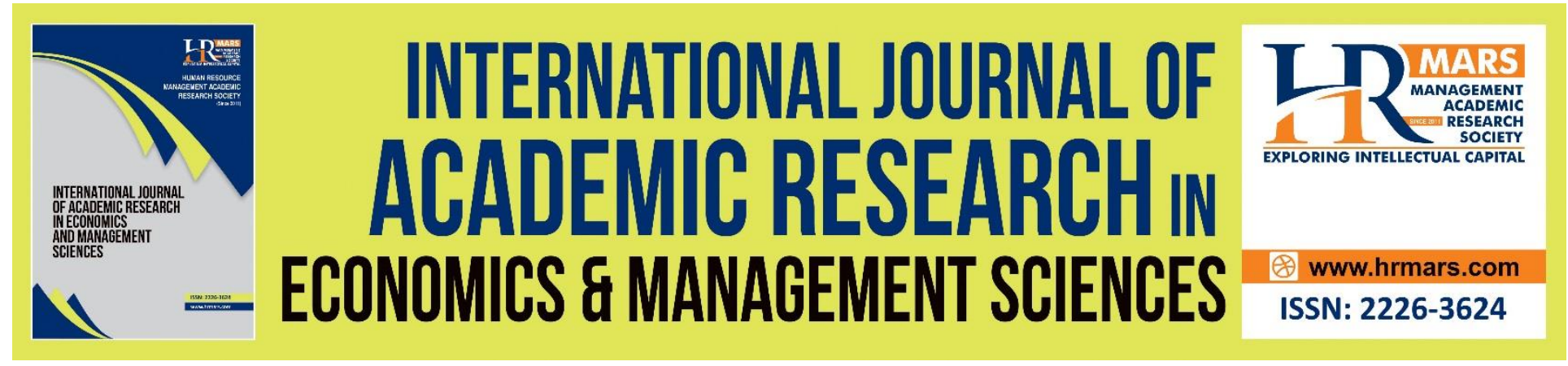

\title{
The Stages of Development of The Transition Economy: The Case of Azerbaijan
}

\author{
Mehmet Gunes, Hafize Hajiyeva
}

To Link this Article: http://dx.doi.org/10.6007/IJAREMS/v9-i2/7841

DOI: $10.6007 /$ IJAREMS/v9-i2/7841

Received: 02 March 2020, Revised: 09 April 2020, Accepted: 06 May 2020

Published Online: 27 June 2019

In-Text Citation: (Gunes, \& Hajiyeva, 2020)

To Cite this Article: Gunes, M., \& Hajiyeva, H. (2020).The Stages of Development of The Transition Economy: The Case of Azerbaijan. International Journal of Academic Research in economics \& Management Sciences. 9(2), 89-101.

\section{Copyright: (c) 2020 The Author(s)}

Published by Human Resource Management Academic Research Society (www.hrmars.com)

This article is published under the Creative Commons Attribution (CC BY 4.0) license. Anyone may reproduce, distribute, translate and create derivative works of this article (for both commercial and non-commercial purposes), subject to full attribution to the original publication and authors. The full terms of this license may be seen at: http://creativecommons.org/licences/by/4.0/legalcode

Vol. 9, No. 2, 2020, Pg. 89 - 101

Full Terms \& Conditions of access and use can be found at http://hrmars.com/index.php/pages/detail/publication-ethics 


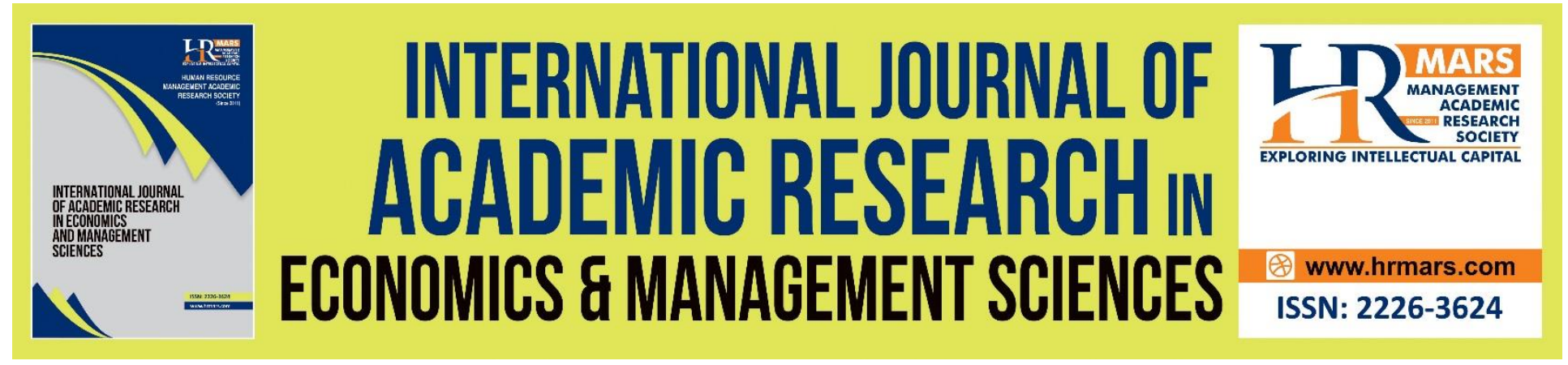

\title{
The Stages of Development of The Transition Economy: The Case of Azerbaijan
}

\author{
Mehmet Gunes ${ }^{1}$, Hafize Hajiyeva ${ }^{2}$
}

${ }^{1}$ Adana Alparslan Türkeş Science and Technology University, Adana-Turkey, Faculty of Business International Trade and Finance, Instructor Mehmet Gunes, ${ }^{2}$ Azerbaijan State Agricultural University, Ganja - Azerbaijan, Faculty of Agribusiness and Management - Accounting and Audit

Research Assistant Hafize Hajiyeva

Email: mtgunes@atu.edu.tr, haciyeva.hafiza@mail.ru

\section{Abstract}

The main objective of this research is to give detailed information regarding the stages of development of the transition economy in Azerbaijan. A transition economy is an economy that is changing from a centrally planned economy to a market economy. The formation of socioeconomic relations and the study of the legality of its activities were of significant theoretical and practical importance in the Republic of Azerbaijan during the transition period. When studying the theoretical principles of transition economies in the image of any particular country, it is important to remember that in the early stages of transition, neither the principles of the old economic system nor the new economic system work. In these circumstances, economic relations are often shaped by non-economic, subjective, and external factors. As the two economic systems operate in a transitional period, the mechanism for stabilizing and regulating the mixed economy at the same stage is also different. The transition to a market economy is not sufficiently propagated as a system of economy, which has led to some negative social and economic consequences. The main goal of the transitional period is to create conditions for economic life to be based on natural opportunities and intellectual potential.

Keywords: Transition Economy, GDP, Turnover, Development, Investment.

\section{Introduction}

A new process began with the collapse of the Union of Soviet Socialist Republics (USSR) in 1991. Countries with economies in transition are divided into two main groups according to the IMF classification in 2000. The first group includes countries with economies in transition in Europe and the Soviet Union, such as Central and Eastern Europe (Albania, Bulgaria, Croatia, the Czech Republic, Macedonia, Hungary, Romania, Poland, Slovakia, and Slovenia), the Baltic states (Estonia, Latvia, and Lithuania), Commonwealth of Independent States (Azerbaijan, Russia, Belarus, Georgia, Kazakhstan, Kyrgyzstan, Moldova, Uzbekistan, Tajikistan, Turkmenistan, 
Ukraine, and Armenia). The second group is defined as countries with economies in transition in Asia, such as China, Cambodia, Laos, Vietnam (Celik et al., 2017).

A common feature of the countries of the former Soviet Union and the countries of Central and Eastern Europe is that they are in a transition period from a planned economy to a market economy. However, there are important differences between these countries in terms of initial conditions and the success of reform practices. The transition from a planned economy to a market economy, also called post-socialist transformation, includes about 30 countries spanning Eastern Europe, the former Soviet Union, and Asian countries since the 1990s. Among these countries, there are major structural differences, such as economic infrastructure, political system, geographical location, institutional success, democratic culture, and natural resources (Sakınc, 2005).

However, the transitional state of the economy is not a phenomenon in the recent history of mankind. There were many of them. The economy of a country always turned out to be transitional with a change in the prevailing system of economic relations, due to the exhaustion of the existing system of its development potential. Further progress of society is possible based on a fundamentally different system of economic relations, replacing the obsolete, fulfilled its historical mission in terms of the development of productive forces within the framework of this qualitatively defined state. The transition period is a long historical process during which the whole system of social relations and all aspects of the life of society are fundamentally transformed (Krasnikova, 2005).

The withdrawal of $20 \%$ of the territory from recycling, the fact that more than a million people are refugees, the breakdown of traditional production relations, the existence of an officially abolished administrative command system, and the absence of appropriate market relations in return, the national mentality of the people of the Republic of Azerbaijan and so on have a decisive influence on the nature of economic relations in the Republic of Azerbaijan, which is in the process of transition to a new economic system. From this point of view, the formation of socio-economic relations in our country during the transition period and the study of the regularities of activity are of great theoretical and practical importance.

\section{Review of Related Literature}

The intense studies on the transition economy have been conducted and reported in the literature all over the world. However, it shows different characteristics according to country origin. It has been reported that the transition period and time frames covered by the transition economy are not similar between the countries.

Ure et.al (2019) reported the political independence and growth rates taking into account the impact of openness and growth rates on political independence data from Freedom House. It was also reported that, as a result of the policies pursued by about 30 countries, some countries fell into the group of developed countries. It was concluded that political mistakes impede growth and do not allow the concept of justice to be implemented in countries. Hence, there is an injustice in the distribution of income.

Orujova (2014) examined the challenges ahead in the transition to a market economy. It was noted that one of those tasks is privatization, as well as the optimal functioning of the economy in a market economy, which requires an optimal ratio of large and small enterprises. It was also pointed out that the growth of small enterprises has reduced the level of monopoly. 
With the shade of those developments the "State Program for the Development of Small and Medium Enterprises in the Republic of Azerbaijan (2002-2005)" dated August 17, 2002, was prepared for the development of the enterprise's sector in Azerbaijan.

Brouers, Zavadskas (2006) proposed a new method called MOORA (Multipurpose Optimization Based on Relationship Analysis). According to the model, for instance, the privatization in a transition economy illustrates the application of the method and is used to optimize many aspects. Tandırcıoglu (2002) investigated the problems that arose during privatization in a transition economy. It was noted that privatization is a key element of the transition economy. The study compared the views of groups considering whether privatization should be fast or slow. It was also highlighted the importance of private sector development in transition economies and, using the EBRD (European Bank for Reconstruction and Development) report, in 1999, in 20 transition economies out of 26, the private sector generated more than 50 percent of the national product.

Aghaev (2011) examined the relationship between exports and economic growth in 12 former Soviet Republics. The export of raw materials, energy, agricultural products, and mining materials constitute the major part of the total export of these countries. It was indicated that there is not causality runs from export growth to economic growth. It was also highlighted that a common feature of less developed countries is a low level of investment due to low income. As a result, production expansion and economic growth are slowing due to the lack of sufficient investment in physical capital. Rosenberg and Saavalainen (2003) noted that the oil-rich former Soviet republics around the Caspian Sea faced double difficulties in their transition to a market economy, the transition to a market economy, and structural changes associated with the oil sector, respectively.

Fischer and Sahay (2000) summarized the macroeconomic performance of the transition economies in their report. It was pointed out that the privatization and reforms help economic growth. Adequate legal framework and financial system are the main conditions for privatization. The higher the speed of reform, the higher the growth. Hunya (2017) believed that during the transition from a transition economy to a market economy, FDI (Foreign Direct Investment) provided access to the technology and knowledge about the market. The EU Member States of Central and Eastern Europe (EU-CEE) were forced to rebalance their balance of payments to adjust to lower capital inflows and experienced low rates of economic growth for some years. During 2010-2012 and 2013-2015, capital in GDP and FDI were studied in many countries.

\section{Research Methodology}

In this study, a general overview of the economy in the transition of Azerbaijan was carried out. The main purpose of the research is to analyze the transition period of the Republic of Azerbaijan to a market economy and study the work done by the state in this field. The study also focuses on the formation of socio-economic relations in the country during the transition period and the study of the patterns of activity. Since the most important indicator determining the tendency of any country to move towards the market is GDP, the GDP growth rates in Azerbaijan for 1990-2019 have been deeply studied. It is worth noting that one of the factors which characterize the transitional economy and contribute to its formation is the fundamental restructuring of foreign economic relations in accordance with changing requirements. Moreover, identifying the opportunities to increase export potential would make a huge 
contribution to enhancing the structure and volume of imports which would help to solve the socio-economic problems of Azerbaijan. This study is also spotted out the dynamics of foreign trade turnover in Azerbaijan for 1990-2016 in the framework of the statistical indicators.

\section{The Growth Rate Of The Transition Economy}

Various indicators are used to determine the market orientation of any country. The most important of these is the specific gravity of the entire product. However, the increase in the share of this indicator reflects the formation of the principles of a market competition system in a country. 
INTERNATIONAL JOURNAL OF ACADEMIC RESEARCH ECONOMICS AND MANAGEMENT SCIENCES Vol. 9, No. 2, 2020, E-ISSN: 2226-3624 @ 2020 HRMARS

Table 1: GDP Growth Rate, ( 1990-2019)

\begin{tabular}{|c|c|c|c|}
\hline Years & $\begin{array}{l}\text { Million Manat[1] } \\
\text { (AZN) }\end{array}$ & $\begin{array}{l}\text { Million Dollars[2] } \\
\text { (USD) }\end{array}$ & $\begin{array}{l}\text { Relative Deviation } \\
\text { (Dollar) }\end{array}$ \\
\hline 1990 & 0,3 & - & - \\
\hline 1991 & 0,5 & - & - \\
\hline 1992 & 4,8 & - & - \\
\hline 1993 & 31,4 & 0.27 & - \\
\hline 1994 & 374,7 & 3.18 & 11.78 \\
\hline 1995 & 2133,8 & 0.51 & 0.16 \\
\hline 1996 & 2732,6 & 0.61 & 1.19 \\
\hline 1997 & 3158,3 & 0.77 & 1.26 \\
\hline 1998 & 3440,6 & 0.88 & 1.14 \\
\hline 1999 & 3775,1 & 0.97 & 1.1 \\
\hline 2000 & 4718,1 & 1.08 & 1.11 \\
\hline 2001 & 5315,6 & 1.16 & 1.07 \\
\hline 2002 & 6062,5 & 1.27 & 1.09 \\
\hline 2003 & 7146,5 & 1.46 & 1.15 \\
\hline 2004 & 8530,2 & 1.73 & 1.18 \\
\hline 2005 & 12522,5 & 2.55 & 1.47 \\
\hline 2006 & 18746,2 & 20376 & 7990.6 \\
\hline 2007 & 28360,5 & 32598 & 1.6 \\
\hline 2008 & 40137,2 & 47782 & 1.47 \\
\hline 2009 & 35601,5 & 44501.9 & 0.93 \\
\hline 2010 & 42465,0 & 53081 & 1.19 \\
\hline 2011 & 52082,0 & 65103 & 1.23 \\
\hline 2012 & 54743,7 & 69295.8 & 1.06 \\
\hline 2013 & 58182,0 & 74592 & 1.08 \\
\hline 2014 & 59014,1 & 75659 & 1.01 \\
\hline 2015 & 54380,0 & 69717.9 & 0.92 \\
\hline 2016 & 60425,2 & 38487 & 0.55 \\
\hline 2017 & 70337,8 & 39515.6 & 1.03 \\
\hline 2018 & 80092,0 & 47112.9 & 1.19 \\
\hline 2019 & 81681,0 & 48047.6 & 1.01 \\
\hline
\end{tabular}

[1]State Statistics Committee of the Republic of Azerbaijan [2]Central Bank of the Republic of Azerbaijan

One of the most important and significant trends in the transition to a new economic system is the development of the private sector. Because the degree of transition to market relations is primarily associated with ensuring the dominant position of private property in the structure of public property in society. The private property right is a combination of the rights of individuals protected by law in the field of means of production, non-productive items, and resources, cash and securities, their use and disposal (Law Of The Republic Of Azerbaijan, 1991). 
The transition to a system of free economic relations based on private property, free enterprise, and healthy competition required radical changes in property relations and economic liberalization. It can be said that at a period when more than $95 \%$ of the property was under state control, privatization became an actual problem. Under the leadership of national leader Heydar Aliyev, property reforms and the privatization of state property came to the fore at the government level, in discussions with economic organizations, economists, scientists, and sociopolitical organizations (Property Reform and Privatization In Azerbaijan, 2019).

There are differences between countries regarding privatization. The main issue here is people's views on privatization. One of the key features of a market economy and the transition to a market economy is privatization. Therefore, the main condition for the transition to a market economy is the support of the people of privatization. Without this support, the expected success will not be achieved (Tandırcıoglu, 2002).

One of the most visible economic processes during the transition period is the reproduction of the economic basis of imbalances at the macroeconomic level. The experience of countries that switched to a new economic system, especially those that gained independence at the same time, shows that the imbalances inherited from the old society are not only in the process of transition for a long time, but even deepen and create new ones.

In the economic literature, the transition period is conditionally divided into the following stages. At the initial stage of the transition period, a shortage of goods is felt in society, and as a result of rising inflation, the existing consumer market is virtually destroyed. During the transition period, the monopoly has a strong influence on rising prices in the sphere of inflation. On the other hand, the experience of our country over the years has shown that the credit policy pursued at this stage has a strong impact on the collapse of economic potential, the nature of financial and monetary relations, especially the strengthening of inflation. Thus, one of the most important factors in the deepening socio-economic crisis in our country should be considered a large number of unsecured, in many cases unreasonable and a significant part of the unpaid loans granted in Azerbaijan in 1990-1994 (Bayramov, 2019).

The second stage of the transition period is characterized by a shortage of goods, a sharp decrease in the purchasing power of the population, and the saturation of the commodity market with relatively cheap, low-quality goods. This famous process was observed in the Republic of Azerbaijan in 1995-1996.

The third stage of the transition period is considered in the economic literature as a stage of more lost opportunities. At this stage, an attempt is made to analyze economic processes during the transition period, and in the early stages of the transition to market relations, euphoria in society is gradually replaced by pragmatic trends. Again, government intervention in the management and organization of economic processes is intensifying.

After discussing the different aspects of the transition economy from a theoretical perspective, the following policies that were applied in Azerbaijan were discussed. At the end of 1992, a law on privatization which was provided primarily for the privatization of taxis was adopted in Azerbaijan. The State Program for the Privatization of State Property in the Republic of Azerbaijan for 1995-1998 was approved by the National Council No. 1120 on September 29, 1995 (The State Program For The Privatization of State Property in the Republic of Azerbaijan for 1995-1998, (1995). The coefficients applied to the initial price of privatized state-owned enterprises (objects) were determined in accordance with the Law of the Republic of Azerbaijan 
"On privatization of state property", and State program of privatization of state property in the Republic of Azerbaijan", "Regulation on the assessment of privatized state property" and other normative legal acts approved by Decree No. 432 of the President of the Republic of Azerbaijan dated December 23, 2000 (Ibrahimov and Mahmudova, 2008).

The transition to a market economy opposes two concepts - "pricing" and "price formation". Pricing is the formation of prices in the consumer market based on principles favorable to producers and consumers, arising from the quality of products, social protection of the population, the economic interests of the state. It is also a process of forming dynamics, structure, and price level, creating a unified system to ensure proportions of social reproduction in a certain period following the laws of economic development. In a market economy, the concept of "price formation" is preferred due to the high role of administrative factors in the pricing process. In the period of transition to economic management methods, of course, the process of "pricing" should prevail (Valiyev et.al., 2001).

\section{The Causes Of The Transition Crisis}

The first group of economists is trying to explain the transition crisis by more subjective factors. Economists with this approach, primarily looking for the causes of the crisis in the mistakes of reformers during the transition period, believe that if the country was controlled wisely, the current crisis and a decline in production would not have occurred. The second group of economists is trying to explain the cause of the crisis with the real socio-economic situation in the country on the eve of the transition. The main attention here is paid to both objective and subjective reasons. Another group of economists considers the collapse of the planning system and the creation of new market relations as one of the main causes of the transition crisis. In fact, this justifies the idea that no matter how focused and effective economic reforms are, the existence of a transitional crisis exists as an objective necessity. In other words, the transition crisis is seen as a necessary condition for economic reform and its nature. The theory of an ideal transition occupies a special place among ideas about a transitional crisis. This theory is actually based on the denial of the existence of the three factors mentioned above. This implies that the rules of conduct for business entities should be oriented in accordance with changing circumstances. In such conditions, the decline in production is considered a natural phenomenon at this stage. It should be noted that the role of subjective factors is gradually weakening compared to the initial stage of the reform, and after a while, the tendency to adapt to new changing conditions intensifies, and the embryos of the market system are already beginning to take shape. As the economy recovers, the factors of the ideal transition theory are becoming increasingly important. All this gives us reason to conclude that the transition from a planned economy to a market economy is a long and complex process. The duration of this stage in each country can vary depending on the starting point of economic development, external factors, national mentality, social environment, and, finally, political stability.

In the transition to a market economy, the state performs several specific economic functions (Shakaraliev, 2009)

1. Denationalization and privatization of the economy, development of entrepreneurship.

2. Creation of market infrastructure, including commodity and stock exchanges.

3. Achieving market equilibrium through the liberalization of the economy and the creation of a competitive environment. 
4. Price liberalization, pricing based on the ratio of supply and demand.

5. Implementation of financial and economic stabilization in the country, which provides for the implementation of a reasonable monetary policy.

6. Creation of a strong social protection system to ensure the adaptation of the corresponding part of the population to a market economy.

7. Social orientation of the economy based on an active structural and investment policy in order to meet the needs of the population.

In general, the contradictions of the transition period can be grouped as follows: The most stable and most frequently observed contradictions of the economic system are directly related to the system of economic relations of society. They are associated not only with forms of ownership, living standards of the population but also with national traditions, ideological views, and so on. As a rule, these conflicts cannot be resolved by forced economic and administrative means, because new conflicts usually arise and develop during evolution within the framework of the old economic system.

The second group of contradictions is an important aspect of the contradictions that operate during the transition period in the absence of a conceptual framework for reforms, measures taken, system models, criteria, and the regulatory framework for reforms. The nature of these contradictions is significantly affected by the deep contradictions inherited from the command economy, prices, finances, and loans, the tax system, as well as between production, distribution, and consumption.

An important aspect of the third group of contradictions in the transition period is associated with the mechanism of action of socio-economic processes in the reform process, as well as the form and nature of regulatory tools. This is primarily due to the price, the structure of financial and monetary circulation, in other words, the economic policy that exists and is implemented during the transition period. It is known that the transition to market relations requires solving complex problems, such as denationalization, privatization of the economy, development of entrepreneurship, the formation of market infrastructure, the gradual weakening of state control over prices, and others.

An analysis of the socio-economic processes during the transition years shows that an exaggeration of the role of market relations and, conversely, an underestimation of the role of the state regulation mechanism and the preference for monetary factors exacerbate the contradictions of the transition period. A historical study of the process of transition to the market of individual countries shows that the above-mentioned contradictions need to be resolved at the optimal time with the minimum possible losses, to ensure the development, preparation, and implementation of a system of political, economic, organizational, managerial and legal measures that take into account national and economic realities, the social environment, national mentality and, finally, external and political factors.

One of the factors characterizing the transition economy and giving impetus to its formation is associated with a fundamental restructuring of foreign economic relations following changing requirements. The main problem in this area is to identify opportunities for increasing export potential, based on the preference for production and service areas that can be activated in the short term during the transition period and to ensure that the structure and volume of imports are aimed at solving socially-economic problems of our republic. 
INTERNATIONAL JOURNAL OF ACADEMIC RESEARCH ECONOMICS AND MANAGEMENT SCIENCES Vol. 9, No. 2, 2020, E-ISSN: 2226-3624 @ 2020 HRMARS

Table:2 Dynamics of Foreign Trade Turnover in Azerbaijan, (Billion \$) (1991-2016)

\begin{tabular}{|l|l|l|l|}
\hline Years & Turnover & Import & Export \\
\hline $\mathbf{1 9 9 0}$ & 4 & 1.9 & 2.1 \\
\hline $\mathbf{1 9 9 5}$ & 1.3 & 0.7 & 0.6 \\
\hline $\mathbf{2 0 0 0}$ & 2.9 & 1.2 & 1.7 \\
\hline $\mathbf{2 0 0 5}$ & 8.6 & 4.2 & 4.4 \\
\hline $\mathbf{2 0 0 6}$ & 11.6 & 5.3 & 6.3 \\
\hline $\mathbf{2 0 0 7}$ & 11.8 & 5.7 & 6.1 \\
\hline $\mathbf{2 0 0 8}$ & 54.9 & 7.2 & 47.8 \\
\hline $\mathbf{2 0 0 9}$ & 20.8 & 6.1 & 14.7 \\
\hline $\mathbf{2 0 1 0}$ & 33.2 & 6.6 & 26.6 \\
\hline $\mathbf{2 0 1 1}$ & 44.2 & 9.8 & 34.4 \\
\hline $\mathbf{2 0 1 2}$ & 43.8 & 9.7 & 34.1 \\
\hline $\mathbf{2 0 1 3}$ & 43.6 & 10.7 & 32.8 \\
\hline $\mathbf{2 0 1 4}$ & 39.4 & 9.2 & 30.2 \\
\hline $\mathbf{2 0 1 5}$ & 25.8 & 9.2 & 16.6 \\
\hline $\mathbf{2 0 1 6}$ & 21.7 & 8.5 & 13.1 \\
\hline
\end{tabular}

*The Issues of Strengthening the Export Potential and Azerbaijan's Accession to The World Trade Organization

Table 2 shows the dynamics of foreign trade turnover in Azerbaijan for 1991-2016. Between 1991 and 2005, foreign trade doubled, along with the restoration of the 1991 level. Foreign trade turnover remained at the same level in 2006-2007. Nevertheless, it reached a record level of $\$ 54.9$ billion in 2008 due to rising oil prices to $\$ 147$ per barrel. In subsequent years, foreign trade was unstable and was mainly regulated by falling or rising oil prices, since oil was the main export commodity. In 2015-2016, the downward trend intensified, and according to the results of 2016, the foreign trade turnover amounted to $\$ 21.7$ billion. In 2016, the export volume amounted to only 13.1 billion dollars. For comparison: in 2008 this indicator amounted to 47.8 billion dollars, in 2010 - 26.6 billion dollars, and in 2015 - 16.6 billion dollars (Aliyev,2017).

Along with mutual trade, the attraction of foreign investment in this process, as well as the extensive use of opportunities for economic integration and international cooperation are important in the effective solution of the problem of foreign economic relations. Also, while solving these problems, the creation of the material basis of the economic security system of our republic should not be overlooked.

\section{Conclusion}

The economy of the Republic of Azerbaijan was in crisis in the early days of independence. Local production has almost completely ceased. In such a situation, the only way out for a country with completely depleted reserves in the national currency was to revive the national economy by attracting foreign investment. Due to this factor, the main feature of Azerbaijan's investment policy at that time was attracting more foreign investment in the oil sector. Investments in this sector have increased from year to year since the signing of the "Contract of the Century" on September 20, 1994, at the initiative of national leader Heydar Aliyev. On September 20, 1994, the "Contract of the Century" was signed at the Gulustan Palace in Baku. This 400-page 
agreement on the development and sharing of the Azeri, Chirag, and Guneshli fields located in the deep sea has been drafted in four languages. 13 companies (Amoko, BP, McDermott, Yunocal, SOCAR, LUKOIL, Statoil, Exxon, Turkish Petroleum, Benzoyl, Itochu, Remco, Delta) from 8 countries (Azerbaijan, USA, Great Britain, Russia, Turkey, Norway, Japan, Saudi Arabia) took part in the "Contract of the Century" (Bayramov, 2019).

At present, this policy is successfully pursued by President Ilham Aliyev. The main feature of Azerbaijan's modern investment policy is determined by achieving the high development of the Azerbaijani economy by completely reducing its dependence on oil and directing oil revenues to the non-oil sector. The share of the non-oil sector in GDP, as well as the volume of investments in the non-oil sector, are growing every year. After the restoration of state independence in 1991, the Republic of Azerbaijan began to pursue an independent policy. The main directions of this policy were the economic system created based on various forms of ownership, the transition to a market economy, and integration into the global economy.

The current economic development of the country since independence can be divided into two main stages: the first stage is a period of economic chaos or recession, covering 19911995; the second stage is a period of macroeconomic stability and dynamic economic development, which began in 1996. Several socio-economic problems arose in Azerbaijan during the transition period. The successful implementation of the oil strategy has played a key role in solving this problem (Aliyev and Shakaraliev, 2002). At that time, many steps were taken to bring Azerbaijani oil to world markets. These include the commissioning of export oil pipelines BakuNovorossiysk in 1996, and Baku-Supsa in 1999, and the signing of an agreement on the construction of the main export pipeline Baku-Tbilisi-Ceyhan. The State Oil Fund was established by the decree of Heydar Aliyev in 1999. The Republic of Azerbaijan became a member of the World Bank's International Monetary Fund, the European Bank for Reconstruction and Development, the Islamic Development Bank in 1992, and the Asian Development Bank in 1999 (President of Azerbaijan, 2020).

\section{References}

Aliyev, A., and Shakaraliev, A. (2002), Transition to A Market Economy: State Economic Policy, Neşriyyat Publishing, Baku.

Aliyev, S. (2017), The Issues Of Strengthening The Export Potential And Azerbaijan's Accession To The World Trade Organization, No.4, page.14-20, Available at: http://www.au.edu.az/upload-files/menu/ipekyolu/2017_4/2AliyevSh.pdf

Bayramov, V. (2019), The Official Opening of The Baku-Tbilisi-Ceyhan Main Export Oil Pipeline Was a Celebration of The Oil Strategy, "Xalq Qazeti" Newspaper, 2019,13 July. Available at: http: //files.preslib.az/site/10il/gl3.pdf

Celik, T., Celik, B., Barak, D. (2017), Real Exchange Rate and Economic Growth Relationship in Transition Economies, Suleyman Demirel University the Journal of Faculty of Economics and Administrative Sciences Y.2017, Vol.22, No.3.

Central Bank of the Republic of Azerbaijan (2020), Available at: https://www.cbar.az/currency/custom\#page-71.

Krasnikova, E. V. (2005), Economy of Transition of The Period, Omega-L Publishing, Moscow.

Law of The Republic of Azerbaijan On Property in The Republic of Azerbaijan (1991), November 9, 1991 No. 256-XII, Baku, Available at: http://www.e-qanun.az/framework/10221 
INTERNATIONAL JOURNAL OF ACADEMIC RESEARCH ECONOMICS AND MANAGEMENT SCIENCES

Vol. 9, No. 2, 2020, E-ISSN: 2226-3624 @ 2020 HRMARS

Pasha, T. (2010), Effective Use Of Financial, Monetary and Currency Mechanisms To Protect Against The Effects Of The Crisis, "Xalq Qazeti" Newspaper, 2010, August 14, P.3, Available at: http://anl.az/down/meqale/xalqqazeti/2010/avgust/130388.htm

President of Azerbaijan (2020), Oil and Gas Projects, Available at:

https://president.az/pages/11/print

Property Reform and Privatization in Azerbaijan: Socio-Economic Consequences and Development Trends (2019), Available at:

Http://Www.Stateproperty.Gov.Az/News/View/222-Az\%C9\%99rbaycanda-

M\%C3\%Bclkiyy\%C9\%99t-Islahatlar\%C4\%B1-V\%C9\%99-

\%C3\%B6z\%C9\%99II\%C9\%99\%C5\%9fdirm\%C9\%99:-Sosial-lqtisadi-

N\%C9\%99tic\%C9\%991\%C9\%99r-V\%C9\%99-Inki\%C5\%9faf-Meyill\%C9\%99ri

Sakınc, S. (2005), Transition Economies and Economic Reforms in Central Asian Turkish Republics, Emek Publishing.

Shakaraliev, A. (2009), Economic Policy of The State: Realities and Prospects, Baku, Available at: http://anl.az/el/alf25/sha_disr\&p.pdf

State Statistics Committee of The Republic of Azerbaijan,(2020), Available at: https://www.stat.gov.az/source/system_nat_accounts/

Tandırcıoglu, H. (2002), Privatization in Countries with Economies in Transition, Dokuz Eylul University, Journal of The Institute of Social Sciences, Volume 4, Number 198.

Üre, S., Sadeghzadeh, K., Karaköy, C., Emsen, O. S. (2019), The Effect of Economic Growth and Openness on Political Freedom in Transition Economies, 3th International Social Sciences Conference, 28-30 June, Sivas.

Orujova, V. (2014), Formation and Development Stages of The Transition Period, Available at: http://az.strategiya.az/news.php?id=14087

Brauers, V. K. M., and Zavadskas, E. K. (2005), The MOORA Method and Its Application to Privatization in A Transition Economy, Control and Cybernetics, volume 35, no 2.

Aghaev, S. (2011), Relationship Between Export and Economic Growth: Panel Counteraction and Panel Causality Analysis in 12 Transition Economies Case, Ege Academic Review, Volume 11, Issue 2, April, p. 241 - 254.

Rosenberg, C. B., and Saavalainen, T. O. (2003), How to Deal with Azerbaijan`s Oil Boom? Policy Strategies in A Resource-Rich Transition Economy, International Monetary Fund, Available at:

https://books.google.az/books?hl=ru\&lr=\&id=79KvaHxCxQsC\&oi=fnd\&pg=PT34\&dq=transition +economy\&ots=aV5SEjPMpk\&sig=0YzOGB0GOHg0SfVUsD44eOeJ054\&redir_esc=y\#v=0 nepage \&q\&f=false

Fischer, S., and Sahay, R. (2000), The Transition Economies After Ten Years, International Monetary Fund, Available at:

https://books.google.az/books?id=khe3WICKsssC\&pg=PA3\&lpg=PA3\&dq=transition+eco nomy\&source=bl\&ots=IZtfknpk5L\&sig=ACfU3U3m4XOuugSzo2AdUecJzXysnLjZA\&hl=ru\& sa $=X \&$ ved=2ahUKEwjiOPO1wMLqAhVJaJoKHd4ADUE4RhDoATACegQICRAB\#v=onepage $\& q=$ transition\%20economy\& $f=$ false

Hunya, G. (2017), Ex-Transition Economies' FDI Recover, Available at: https://wiiw.ac.at/extransition-economies-fdi-recovery-n-239.html 
INTERNATIONAL JOURNAL OF ACADEMIC RESEARCH ECONOMICS AND MANAGEMENT SCIENCES Vol. 9, No. 2, 2020, E-ISSN: 2226-3624 @ 2020 HRMARS

The State Program For The Privatization of State Property in the Republic of Azerbaijan for 1995-1998 (1995), Available at: http://85.132.71.30/framework/9472

Ibrahimov, T. A., and Mahmudova, M. T. (2008), Accounting and Audit of Privatized Property, University of Economics Publishing House, Baku

Valiyev, T. S., Babayev, A. P., Meybullayev, M. X. (2001), Economic Theory, Chashoglu Publishing House, Baku 